\title{
V Peru sa ešte nosí občianska odvaha a vzdor proti arogancii moci a kapitálu
}

\section{Mikuláš Huba}

\section{Envigogika 9 (2) - Inspirace/ Inspirations}

Publikováno/Published 31. 10. 2014

DOI: $\underline{10.14712 / 18023061.455}$

\begin{abstract}
Abstrakt:
Mikuláš Huba se v červnu 2014 zúčastnil dvoutýdenní studijní cesty po Peru, a to jako člen 17ti členného týmu účastníků z devíti zemí. Akci organizovala mezinárodní nevládní organizace Climate Alliance $v$ rámci projektu Od nadspotřeby $k$ solidaritě, jejímž cílem je zvýšit povědomí Evropanů o globálních důsledcích nadměrné spotřeby prírodních zdrojů. $\checkmark$ rozhovoru s účastníkem cesty jsou představeny jeho nejzajímavější zážitky; samotné Peru se zde ukazuje z hlediska svých př́rodních krás i environmentálních problémů.
\end{abstract}

\section{Klíčová slova:}

Peru; přírodní podmínky; udržitelná výroba a spotřeba; regionální a místní ekonomika

\begin{abstract}
:
In June 2014, Mikuláš Huba undertook a forthnight's trip around Peru where he was part of a team consisting of 17 members from 9 countries. The trip was organized by the international Climate Alliance NGO as part of the project From Overconsumption to Solidarity, the purpose of which is to raise awareness among Europeans of the global consequences of the overconsumption of natural resources. Mikulás's experiences from the journey and Peru are presented in an interview from the point of view of the country's natural beauty and its environmental problems.
\end{abstract}

\section{Key words:}

Peru; natural conditions; sustainable production and consumption; regional and local economy 
V júni 2014 si sa zúčastnil dvojtýždňovej študijnej cesty po Peru. Ako si sa tam ocitol a s kým?

Ocitol som sa tam vcelku nečakane, ako člen 17-členného tímu z deviatich krajín. Ako jediný Slovák som sa tam dostal na základe odporúčania mimovládnej organizácie CEPA Priatelia Zeme Slovensko.

Podujatie organizovala medzinárodná mimovládna organizácia Climate Alliance $\checkmark$ rámci projektu Od nadspotreby $\mathrm{k}$ solidarite, $\mathrm{v}$ ktorom vedúcu úlohu zohráva luxemburská mimovládka Action Solidarité Tiers Monde (ASTM), ktorá je spolu $s$ ekologickou MVO Ekologické hnutie národným koordinátorom Climate Alliance Luxembourg s 37 členskými organizáciami. Hlavným ciel'om projektu ASTM je zvýšit verejné povedomie Európanov o globálnych dôsledkoch nadmernej spotreby prírodných zdrojov Európanmi, ich vplyvu na prírodné zdroje a životodárne systémy našej planéty, upozornit' na limity globálneho ekosystému a zdôraznit́ sociálne, ekonomické a ekologické dopady rozvoja, prebiehajúceho $v$ krajinách globálneho Juhu. Študijná cesta bola financovaná čiastočne $z$ fondov EÚ a čiastočne z vlastných prostriedkov účastníkov.

Ked' sa povie Peru, asi ako prvé človeku naskočia asociácie: Indiáni (Machu Picchu, Inkovia), zlato, Pacifik, Lima, jazero Titicaca, Andy, ale aj amazonský prales... Čo $z$ toho si videl počas Tvojej cesty?

Nešlo o turistiku, ale o pracovnú cestu, takže z najväčších turistických hitov som toho vela nevidel. Ale strávil som po pár dní v každom z troch hlavných makroregiónov, z ktorých pozostáva táto tretia najväčšia krajina Južnej Ameriky, teda pás púštnych nížin pri pobreží Pacifiku, kde leží aj hlavné mesto Lima, Andy (vrátane štvortisícových kopcov a historicky významného mesta Cajamarka, kde sa vlastne začala vítazná cesta španielskych dobyvatelov a tragédia Inkov), až po amazonské pralesy so slávnymi mestami, ako sú Iquitos či Nauta.

\section{Zlaté bane... Aj na Slovensku celkom frekventovaná téma. Dá sa porovnat' množstvo zásob zlata v Peru s tými slovenskými? A dá sa porovnat' spôsob táazy? Jestvuje nejaká peruánska technologická tažiarska inšpirácia pre Slovensko?}

Zásoby zlata v Peru sú neporovnatel'ne väčšie ako na Slovensku a aj tamojšie bane na zlato patria medzi najväčšie na svete. A najväčšia t́ažba sa čiastočne realizuje a čiastočne ešte len hrozí pri prameňoch najvodnatejšej rieky sveta Amazonky, čo je z globálneho hl'adiska riziko o pár rádov väčšie ako prípadné znečistenie ktorejkolvek zo slovenských riek. Navyše sa tam devastuje krásna vysokohorská krajina s prekrásnymi plesami, ktoré miestni nazývajú lagúny. Technológia tažby s premiestňovaním celých kopcov je podobne brutálna, ako tá, ktorá sa navrhuje na Slovensku, len na lúhovanie sa nepoužíva kyanid, ale iné, podla všetkého podobne nebezpečné látky. Medzi nimi smutne dominuje ortut́ s katastrofálnymi následkami na všetko živé $v$ povodí dotknutých amazonských prítokov. Inak inšpirácií a paralel so Slovenskom a zamýšlanou tažbou zlata pri Detve a Kremnici som tam zažil dost' vela. Od korupcie a arogancie developerov, cez argumentovanie potrebou rozvoja a kvázikompenzácie zničeného prostredia $v$ podobe financovania neužitočných projektov až po odhodlanie miestnych ludí a mimovládok bojovat' proti developerom prinášat' pre to aj tie najväčšie obete. Na jednej z menších demonštrácií sme sa mali možnost' zúčastnit́ a bolo mi smutno z toho, že éra občianskej odvahy a nenásilných "priamych environmentálnych akcii" na Slovensku už akoby prestala existovat'. 


\section{Boli ste aj pri Amazonke - ako na Teba zapôsobila? Pre Stredoeurópana je to rieka plná piraní, lemovaná nepriestupným pralesom, obývaným divou zverou a pôvodnými kmeňmi Indiánov. Predpokladám, že realita je ale celkom iná...}

Strávili sme tam len necelé štyri dni, ale navštívili sme nielen obe najväčšie mestá $\checkmark$ peruánskej časti povodia Amazonky, ale aj domorodé osady pri bočných ramenách najväčšej rieky sveta. Plavili sme sa niekolko hodín po jednej z najväčších zdrojníc Amazonky, rieke Maraňón. Užívali sme si večery na "havansky" schátralej promenáde bývalej svetovej metropoly táǎby kaučuku, dnes 400-tisícového Iquitos, jediného velkomesta na svete bez cestného či železničného spojenia s civilizáciou, ale zato plného motorových rikší. Vel'mi zaujímavá bola tiež návšteva školy, kde sa reprezentanti domorodých kmeňov učia "za učitel'ov". Pracuje tam aj vel'mi sympatická pani Jenny Jovita Panduro Urrelo, ktorá absolvovala Ekonomickú univerzitu v Bratislave na prelome 80. a 90. rokov minulého storočia. Nielenže ešte stále hovorí celkom dobre po slovensky, ale pamätá si aj slovenské ludové pesničky. Bola št́astná, že po dlhých rokoch našla opät živého Slováka a mohla sa s ním porozprávat́. Mal som pocit, že už dávno som nikomu takú radost́ neurobil. Aj takéto nečakané stretnutia dávajú cestovaniu zmysel...

\section{Ale napríklad divú zver sme stretli iba na tanieri.}

Paradoxne najväčší dojem na mňa urobila Amazónia vtedy, ked'sme nad ňou niekolko hodín leteli, pričom s výnimkou okolia spomínaných dvoch miest som žiadne stopy civilizácie nezaznamenal - iba nekonečný prales popretkávaný prítokmi Amazonky, bočnými ramenami, jazerami, mokrad’ami a smerom k ústiu samotným veltokom Amazonkou s nepredstavitel'nou šírkou miestami až desiatok kilometrov. Je jasné, že realita nie je až taká idylická ako pohlad z výšky desiatich kilometrov, ale ved'aj taká Bratislava je pekná pri pohl'ade z televíznej veže na Kamzíku a najmä v noci, nie?

\section{Vážia si Peruánci svoje bohatstvo - drevo z amazonských lesov? Či sa ho (ako my) nerozumne zbavujú exportom?}

Tragédia rúbania amazonského pralesa sa nevyhla ani Peru, napriek tomu, že aj tam pribúda obrovských chránených území a rastie povedomie o nenahraditel'nom význame amazonského pralesa pre lúudstvo.

Okrem toho, čo je možné vidiet' "vol'ným okom", je nebezpečné to, čo hrozí v budúcnosti, lebo čím d’alej tým viac pôdy sa dostáva do rúk súkromných firiem a spoločností, ktoré si "brúsia zuby" na prírodné bohatstvo Amazónie, ktoré ani zd'aleka nereprezentujú len drevo a pôda. $\vee$ regióne sa nachádzajú aj vel'ké zásoby nerastných surovín, zlata, ropy, zemného plynu a pod. Pomôct' miestnym obyvatel'om bránit' sa je aj jedným z ciel'ov takých projektov, $v$ rámci akého sa uskutočnila aj naša cesta do Peru. Tamojší domorodci vnímajú svet ovel'a bytostnejšie a emocionálnejšie, ako my. Sú integrálnou súčastó prostredia, v ktorom žijú. Mám taký dojem, že väčšina z nich ani netuší, čo ich čaká, ked'sa dobudujú cesty, ktoré sa k nim blížia... Jeden večer sme mali zaujímavú diskusiu na tému existenčnej dilemy: či je lepšie poskytnút miestnym Indiánom vzdelanie a tým im otvorit' cestu do sveta, alebo ich nechat žit' ich životom a tak ich vlastne uchránit' pred "zvodmi” a rizikami civilizácie. Na prvý pohl'ad mi je asi sympatickejšia tá druhá možnost́. Avšak má jednu zásadnú slabinu. Ako sa obyvatelia pralesa ubránia pred rôznymi mazanými developermi, ked' nebudú vediet' nič o ich spôsobe myslenia, právnych "fintách" a pod.? Historické memento tragédie inak kultúrne vel'mi vyspelých Inkov spred piatich storočí je dodnes živé, poučné a varovné. Takže sme tú debatu ukončili akýmsi kompromisom: asi ich treba "pripravit' na život" a kontakt s bielymi, ale tak, aby zostali sami 
sebou, Indiánmi hrdými na svoje obdivuhodné zvyky, kultúru, zručnosti, intuíciu a schopnost' prežitia aj bez modernej techniky, sofistikovanej infraštruktúry i peňazí.

\section{Na čom je vlastne založená ekonomika Peru?}

Čast' príjmov pochádza z cestovného ruchu, čast' z "darov mora". Niečo vyprodukujú aj miestne pol'nohospodárstvo (vrátane koky), priemysel, doprava a remeslá, ale velkú čast́ HDP tvorí vývoz surovín a polotovarov. Či už na báze rudného bohatstva Ánd, alebo dreva a iných darov amazonského pralesa. Najväčším zdrojom nelegálnych príjmov donedávna bol (a podla neoficiálnych údajov aj nad'alej je) kokaín. V roku 1984 sa čistý zisk z obchodu s kokaínom odhadoval na takmer 3 miliardy dolárov. Malo to vel'mi negatívne dôsledky nielen na nárast násilia, krvavého teroru až guerillových vojen s desiatkami tisícov mítvych, ale spôsobilo to aj ekologickú pohromu $v$ podobe rúbania pralesa $v$ prospech rýchlo rastúcich políčok koky.

\section{A čo pol'nohospodárstvo? Stretol si sa aj s nejakými ekologickými pol'nohospodármi? A s projektmi Fair Trade?}

Najskôr ak v Lime na letisku a v luxusných obchodoch v meste sa dajú nájst' produkty označené značkou Fair Trade. Ale vlastne všetky horské farmy, ktoré sme videli počas stoviek kilometrov precestovaných v horách, bysme mohli označit' ako biofarmy. Bio sú určite aj produkty Amazonky a pralesa s nepredstavitel'nou pestrostou rastlinných a živočíšnych druhov. Na druhej strane, ako som už naznačil vyššie, tradičné pol'nohospodárstvo s pestovaním plodín ako sú zemiaky, obilie či fazul'a tažko dokáže konkurovat́ ovela lukratívnejšej produkcii koky. K úpadku pol'nohospodárstva však prispieva aj hospodárska politika štátu. Kým ceny pol'nohospodárskych produktov kontroluje štát, cena pohonných hmôt apod. stále rastie, takže náklady pre rolníkov sú stále vyššie a ich reálne príjmy klesajú. Pôda je zásluhou nedostatočnej starostlivosti stále chudobnejšia a úroda polńnohospodárskych plodín (s výnimkou koky) je stále slabšia. Toto však nebola prioritná téma nášho pobytu.

\section{Wikipédia tvrdí, že asi $\mathbf{4 0} \%$ obyvatel'ov Peru žije pod hranicou chudoby - stretol si sa s chudobou? Je tá peruánska chudoba porovnatel'ná s našimi častými slovenskými nárekmi na chudobu a biedu?}

Peruánska chudoba, ako ju ja vnímam, má dve tváre. Tú jednu by som označil ako dôstojnú až hrdú chudobu, či skôr materiálnu nenáročnost' horalov a obyvatelóv pralesa. A potom je to nedôstojná bieda obyvatelov predmestí velkých miest vrátane Limy, porovnatel'ná so životom $v$ našich rómskych osadách, vrátane zaobchádzania $s$ odpadmi, ktoré konča bežne $v$ riekach a na ich brehoch. Ale celkovo som nenadobudol dojem, že by Peru bola zvlášt́ chudobná krajina - centrálna čast' Limy pôsobila nemenej blahobytne a usporiadane ako centrálna čast' takého Paríža, Madridu, Lisabonu či Ríma. Ĺudia, bez ohladu na výšku platu či sociálny status, boli celkovo vel'mi sympatickí, nevtieraví, príjemní, v dobrom slova zmysle hrdí, a zároveň úprimne radi, že sme ich prišli navštívit' až z d'alekej Európy a že nás zaujímajú ich problémy.

\section{Bol si aj v hlavnom meste - v Lime. "Ochutnal" si aj Pacifik? Vraj je pri peruánskom pobreží ohromne bohatý na ryby.}

Bývali sme blízko Pacifiku, aj ked's tou blízkostou je to trochu zložitejšie. Lima totiž neleží priamo pri pobreží, ale na cca 50 metrov vysokej terase, ktorá k oceánu spadá takmer zvislou stenou (útesom), porastenou popínavými vždyzelenými rastlinami, z čoho má 
tunajšie pobrežie aj názov Costa Verde - Zelené pobrežie. A aj ked’ byste niektorou z mála cestičiek zišli na úpätie útesu, od oceánu Vás bude stále ešte oddel'ovat́ dial'nica. Navyše, vd'aka studenému Humboldtovmu morskému prúdu sa $v$ tejto časti Pacfiku nedá bez neoprénu kúpat'. Ale inak to zhora, aj vd'aka nádherným vlnám trieštiacim sa o breh, pôsobí krásnym dojmom a spomínaná horná terasa je plná parkov, vyhliadkových chodníkov, cyklotrás a ihrísk. Na jednom mieste tu vybudovali čosi, ako je bratislavská Eurovea pri Dunaji. A neustále tam lieta kopa rogalistov, ktorí za dost' mastný poplatok radi povozia aj turistov.

\section{Postrehol si v Lime nejaké zaujímavé ekologické riešenia? Či už dopravné, energetické, či týkajúce sa zelene, verejných priestorov alebo podpory miestnej produkcie? Čo z toho by podl'a Teba mohlo fungovat' aj u nás?}

Mali sme asi hodinové stretnutie s najvyššími predstavitel'mi tohto 10-miliónového velkomesta, takže sme sa o ňom dozvedeli pomerne dost' aj z pohl'adu radnice. Za najväčší problém označili rýchly a tážko zvládnutel'ný územný rozvoj, vel'kú imigráciu z vidieka, dopravu, odpady a zásobovanie vodou. Peru je pritom vysoko centralizovaná krajina, takže samospráva má dost́ malé kompetencie, a hlavne vel'mi malý rozpočet. Takmer všetko je $\checkmark$ rukách štátu, vrátane vodárenských spoločností či výstavby metra, ktorá sa má začat́ na budúci rok. Ale l'udia, s ktorými sme sa na pompéznej radnici v Lime stretli, pôsobili vel'mi kompetentným dojmom, vrátane šéfky odboru životného prostredia, ktorá je vzdelaním ekologička, hovorí výborne po anglicky (čo je v Peru skôr výnimka) a environmentálne problémy mesta má evidentne „v malíčku". Vd'aka viac-menej púštnej klíme tu zeleň parkov môže jestvovat́ len vd'aka zavlažovaniu, ale je v ovel'a lepšom stave, ako naša bratislavská. A potom, na každom kroku stretnete zametačov a smetiarov, takže rozsiahla centrálna mestská oblast' Limy je permanentne čistá, a nie ako naše mestá.

\section{V decembri sa bude práve v Lime konat' jubilejný Svetový klimatický summit - „COP 20“. Zaregistrovali ste jeho prípravu počas Vášho pobytu v Peru?}

Áno. Jedno popoludnie sme diskutovali s organizátormi niečoho, čo by sa dalo nazvat́ paralelným summitom MVO s množstvom sprievodných podujatí, ktoré pripravujú počas COP 20. Bolo to vel'mi poučné a užitočné stretnutie: myslím si, že pre obe strany.

\section{A na záver a odl'ahčenie :) Na čom si si v Peru najviac pochutnal?}

Ak myslíš jedlo, tak pochutnal som si na aligátorovi. Ako vtipne poznamenal jeden z účastníkov: vždy lepšie, ako keby si aligátor pochutnal na mne.

Celkom na záver by som sa chcel pod'akovat' všetkým, ktorí/ktoré akýmkolvek spôsobom prispeli k úspešnému priebehu našej "expedície”. Okrem vyššie spomenutých organizácií a finančnej podpory EÚ sú to menovite hlavní organizátori Silke Lunnebach a Roger Martinez-Dolz.

Otázky: Richard Medal

Odpovede: Mikuláš Huba

Bratislava, júl 2014 